\title{
Understanding the Awareness of the Importance of Halal Labels to Business Actors Based on Range of Long Business Variations
}

\author{
Amarul Amarul ${ }^{1}$, Sukirno Sukirno ${ }^{1} \&$ Denny Kurnia $^{1}$ \\ ${ }^{1}$ Universtas Serang Raya, Indonesia \\ Correspondence: Amarul Amarul, Universtas Serang Raya, Indonesia \\ Received: November 30, 2018 \\ Accepted: December 18, 2018 \\ Online Published: January 24, 2019 \\ doi:10.5430/bmr.v8n1p17 \\ URL: https://doi.org/10.5430/bmr.v8n1p17
}

\begin{abstract}
This study aims to determine the level of understanding of halal certification awareness in small and medium micro business actors. The research conducted is a descriptive analysis of quantitative data to determine information on the interests of halal certificates in the eyes of business actors. By using a questionnaire as an instrument. The sample used was 101 business actors with different lengths of operation. The results showed that presents the high actors who have given halal label on the length effort than or equal to 2 years and less than five years, with a percentage of $64.10 \%$. This shows that most business actors who are very concerned with labeling their products are usually those who have run their business more than or equal to 2 years but less than 5 years.
\end{abstract}

Keyword: Halal labels, long business variations

\section{Introduction}

and Growth of technology and industry continues to grow and give birth to various new discoveries in various fields including technology in food, beverage, cosmetics and medicine products, so that the marketing competition that occurs, makes Small and Medium Micro Enterprises (MSMEs) to be able to find, develop and even capture market share from their competitors. In addition to relying on products produced with all kinds of differences and advantages, one of the capital to win the competition is one of them is the halal label. According to Yunus, Rashid, Ariffin, and Rashid (2014) show that the composition of the ingredients contained in the product has a significant positive effect on the interest in buying Muslim consumers because the food is one of the determining factors in predicting how consumers buy an interest in a food product. In Indonesia, the government has passed Law No. 33 of 2014 concerning Guaranteed Halal Products that make all stakeholders stake in this matter inevitably begin to move and strengthen the intention and determination to change the lifestyle into a lifestyle that is lawful conscious. This awareness encourages all elements of society to begin to slowly recognize the products they consume, whether the product can be ascertained halal or not. Halal certification benefits all consumers, not only Muslim consumers, because halal is not only a halal content but also processed in an ethical, healthy and good manner. Muslim consumers, as well as non-Muslims, are looking for products that are halal certified because they want to maintain their health by maintaining their food (Norafni, 2013). Research by Rajagopal, Ramanan, Visvanathan, and Satapathy (2011) indicates that halal certification can be used as a marketing tool in promoting halal products. In this case halal is one of the factors that can influence consumer buying interest, according to Teguh Widodo's (2013) study of Muslim consumers' perceptions of having a positive and significant influence on halal food products. The results of the Khalek (2014) study that 78.2\% agreed that people's perceptions influence their decision in choosing halal or non-halal food outlets. The results of this study are expected to be a motivation for business people to increase the productivity of their business, also expected that the strategic role of business actors in developing the people's economy can be well realized.

\subsection{Theoretcal Basis}

Halal certification is a guarantee of security for a Muslim consumer to be able to choose foods that are good for him and in accordance with religious rules. Food products that have halal certification are products that in the processing process meet standards in safety and cleanliness (Pepper, 2009). The halal label of the product basically covers the scope of food products which in Law No. 7 of 1996 concerning food. As stated in Article 1 paragraph (1) of Law No. 7 of 1996, everything derived from biological and water sources, whether or not processed as food or drink for human consumption, including food additives, raw materials food, and other materials used in the process of preparing, processing and or making food or drinks. According to the LPPOM provisions of the Indonesian Ulema Council in the 
Halal Guarantee Guide, Halal Certification is a process for obtaining halal certificates through several stages to prove that materials, production processes, and FSS meet the standards of LPPOM MUI. a Halal certificate is a written fatwa of MUI which states the halalness of a product in accordance with Islamic Shari'ah. This halal certificate is a requirement to include halal labels on product packaging, with the aim of providing certainty about the halalness of a food, medicine and cosmetics product, so that it can reassure those who consume it. The halal certificate of a product is issued after it has been decided in the session of the MUI Fatwa Commission which was previously based on the audit process conducted by LPPOM MUI. Awareness is the ability to understand, feel, and become aware of an event or thing. Awareness is a concept of implying understanding and perception of events or subjects (Aziz, 2013: 7). Halal awareness is known based on whether a Muslim understands what halal is, knows the correct slaughter process, and prioritizes halal food for them to consume. Awareness of buying and consuming halal products is very important for Muslims. This is because products that are halal certified are not only produced by Muslim producers but also handled by a number of non-Muslim groups (Yunus, 2013). Research (Ardyanti et al., 2013) entitled A Study on Halal Food Awareness Among Muslims Customers in Klang Valley shows that Muslim consumers' awareness of halal food is influenced by their understanding of Halal concepts. From the results of research conducted by Yuli \& Syaad (2012), the results of his research suggest that the inclusion of halal labels on instant noodle packaging has a very significant effect on the interest in purchasing. According to Rahimah Mohamed Yunos (2013) Overall, the success of the halal industry requires coordination and participation of various parties and strategic marketing strategies in addition to various other factors that contribute to placing "Halal" as one of the attributes consumers consider to buy products/services. Andreina Fara (2016) shows that halal certification in restaurants produces a better opinion of restaurants among consumers. In addition, halal certification is also seen as useful for consumers in determining consumer behavior. Yuhanis Abdul Aziz and Chok Nyen Vui (2013) Research conducted by Aziz and Vui entitled "The Role of Halal Awareness, Halal Certification and Marketing Components in Determining Halal Purchase Intention Among Non-Muslims in Malaysia: A Structural Equation Modeling Approach". The study found that halal awareness, halal certificates, marketing promotions, halal brands had a positive effect on the interest in buying halal products while food quality negatively affected the interest in buying non-Muslim consumers in Malaysia. Khalek (2014) in his research indicated the positive attitude of Muslim youth to wards halal food outlets and JAKIM certification. In addition, Teng et al (2013) conducted research on the awareness of non-Muslim consumers in Malaysia on the halal logo and stated that most non-Muslim consumers are aware of halal labeled food and JAKIM Halal logo on food products.

\section{Method}

research conducted was a descriptive analysis of quantitative data to determine information on the interests of halal certificates in the eyes of business actors. This research begins with the stage of making field data collection instruments through the preparation of several questions related to the information that is to be obtained. Furthermore, questionnaires were distributed to 101 business actors with different lengths of operation. The next step is analyzing the data with a statistical approach in order to interpret the results of the study. In this study also the sample of business actors who were used as respondents were entrepreneurs in the Banten Province, especially in Serang District.

\section{Results}

Based on the results of statistical data processing of the obtained several businesses operating duration value ranges as shown in Table 1.

Table 1. Characteristics of Respondents by Length ofBusiness

\begin{tabular}{|c|c|c|}
\hline Old Business & & ntage \\
\hline$<=2$ years & 29 & $28.71>$ \\
\hline$>=2$ years and $<5$ years & 39 & 38,61 \\
\hline$>=5$ years and $<10$ years & 17 & 16.83 \\
\hline$>=10$ years & 8 & 7.92 \\
\hline Blank & 8 & 7.92 \\
\hline
\end{tabular}

Most of the respondents who filled out the questionnaire had run their business between 1 and approximately 5 years. The rest of the respondents involved in this study have been running businesses between 5 and 10 years. From the total respondents and based on the results of the analysis conducted, it is also known that only around $39.60 \%$ of business actors have been concentrated by giving halal labels to their business products (see Table 2). 
Table 2. Respondents' data using halal

\begin{tabular}{lll}
\hline label Halal Label & Amount & Percentage \\
\hline There are & 40 & $39.60 \%$ \\
No & 61 & $60.40 \%$ \\
\hline Total & 101 & $100 \%$ \\
\hline
\end{tabular}

Whereas when viewed in terms of the length of a business actor, most business actors are very concerned with labeling their products usually those who have run their business more than or equal to 2 years but less than 5 years. The research conducted also not only observed business actors with an operating time of more than or equal to 2 years less than 5 years. However, it is also observed for business operators with an operational duration of less than or equal to 2 years, more than or equal to 5 years but less than 10 years and for business operators with a duration of operation of more than 10 years. The results of observations carried out in detail as shown in Table 3 .

Table 3. Percentage of Halal Labels of Business Executors Based on Length of Operation

\begin{tabular}{lllll}
\hline Long Operation & $\begin{array}{l}\text { Number of } \\
\text { Respondents }\end{array}$ & $\begin{array}{l}\text { Halal } \\
\text { There } \\
\text { are }\end{array}$ & $\begin{array}{l}\text { Labels } \\
\text { not }\end{array}$ & $\begin{array}{l}\text { Percentage of Halal } \\
\text { Labels }\end{array}$ \\
\hline$<2$ years & 29 & 1 & 28 & $2.5 \%$ \\
$>=2$ years and $<5$ year & 39 & 25 & 14 & $62.5 \%$ \\
$>=5$ years and $<10$ years & 17 & 9 & 8 & $22.5 \%$ \\
$>=10$ years & 8 & 5 & 3 & $12.5 \%$ \\
Blank & 8 & 0 & 8 & 0 \\
Total & 101 & 40 & 61 & $100 \%$
\end{tabular}

Whereas when viewed from each duration of operation against awareness of providing halal labels on their business products, it can be seen that the percentage of business actors who have not listed the halal label on their products is the highest in the business period of fewer than 2 years, namely $96.55 \%$. The percentage of principals who have provided halal labels for more than or equal to 2 years and less than 5 years is $64.10 \%$. The length of business is more than or equal to 5 years and less than 10 years $52.94 \%$ that has provided halal labels on their products, and the length of business more than or equal to 10 years is only $62.50 \%$ of business actors who have provided halal labels on the product.

Whereas if seen from the awareness related to the understanding of the benefits of halal certificates, it was found that the average value of understanding the importance of halal certificates was 4,509. Basically, business actors perceive that halal certificates in the Kemasana product are very important (SH1). This can be seen from the perceived value of the results of the data analysis of respondents at 4.75. In addition, most business actors still consider that halal certificates are still considered not too important, but indeed become a consideration in the future (SH2). This can be seen from the perception index value of the SH2 indicator of 3.96. Another indicator of understanding that business people know that issuing halal certificates is the authority of the Indonesian Ulema Council. This can be seen from the perceived value of the SH3 indicator of 4.35. In addition, most business people understand that every product that has a halal label will provide a sense of security for its consumers. This can be seen from the perception index value of the SH4 indicator of 4.74. In addition, the perception of business people considers that every product that has halal certification is a product that has high quality. This can be seen from the index value of perception of the SH5 indicator as much as 4.45. Then indicators of awareness of business people that the existence of a halal certificate in a product will provide an increase in sales. It can be seen from the SH6 indicator with an index value of 4.42. Then also indicators of the awareness of business people in producing their products always prioritize the halalness of the products they produce. This can be seen from the value of the SH7 index of 4.65. Another indicator is that business people understand well what is meant by halal. This can be seen from the value of the SH8 index of 4.36. Can be seen in more detail in Table 4. 
Table 4. Descriptive Analysis of Perception of Understanding Halal Certificates for Business Executors

\begin{tabular}{llllll}
\hline & N & Minimum & Maximum & Mean & Std. Deviation \\
\hline SH1 & 101 & 4,00 & 5,00 & 4,7525 &, 43373 \\
SH2 & 101 & 1,00 & 5,00 & 3,9604 &, 81143 \\
SH3 & 101 & 3,00 & 5,00 & 4,3564 &, 57592 \\
SH4 & 101 & 4,00 & 5,00 & 4,7426 &, 43940 \\
SH5 & 101 & 3,00 & 5,00 & 4,4554 &, 53898 \\
SH6 & 101 & 3,00 & 5,00 & 4,4257 &, 55401 \\
SH7 & 101 & 3,00 & 5,00 & 4,6535 &, 49871 \\
SH8 & 101 & 3,00 & 5,00 & 4,3663 &, 54264 \\
Valid & N101 & & & & \\
(listwise) & & & & &
\end{tabular}

\section{Discussion}

Based on the results of the above research, business actors have actually realized and understood halal certification in a product, as evidenced by the results of a questionnaire given to 101 respondents that the awareness and understanding of business actors reached the average level of 4.5 shows that the perceptions of business actors with indicators of awareness and understanding of halal certification are good, but that understanding and awareness are not applied in carrying out their business, after business people create products and make sales, only a small proportion of business actors provide halal labels for products that have already been packaged at $39.60 \%$. And the remaining $60.40 \%$ of the perpetrators do not include halal labels in products that are already packaged and ready for sale. Whereas if viewed from each of the long operating ranges of awareness of halal labeling on its business products, it can be seen that percentage a high of actors who have provided halal labels for the duration of business more than or equal to 2 years and less than 5 years with a percentage value amounting to $64.10 \%$. This shows that most business actors that are very concentrated by labeling their products are usually those who have run their business more than or equal to 2 years but less than 5 years.

\section{Conclusion}

From the results of the above research it can be concluded that many entrepreneurs do not yet have an awareness of the importance of halal labels in each product they produce, starting from a business period of fewer than 2 years to more than 10 years there are $60.40 \%$ of entrepreneurs not including Halal label in the product. The results of this study are expected to be a reference for relevant agencies in providing direction, supervision, and outreach to small and medium entrepreneurs to be more focused and aware of the importance of halal labels. And the results of previous studies have shown that halal labels can influence consumer purchasing decisions. Moreover, with the regulations of Law No. 33 of 2014 which confirms that products that enter, circulate and trade in the Indonesian Territory must be halal certified.

\section{Acknowledgements}

From the results of this study, the authors would like to thank Kemenristek Dikti for providing financial assistance to the academic community of Universitas Serang Raya, which has provided facilities and space, so that this research can be completed according to the time specified.

\section{References}

Andreina Fara, Sri Rahayu Hijrah Hati, Sri Daryanti. (2016). Understanding Halal Restaurant Patronage intention; The Role of Perception, Culture, and Religiosity, The European Proceedings of Social \& Behavioral Science EpSBS e ISSN: 2357-1330. https://www.futureacademy.org.uk/files/images/upload/16_Beci2016.pdf

Ardayanti, A., Nashril, TT A, \& Helmi, A. (2013). A Study on Halal Food Awareness among Muslims Customers in Klang Valley, 4th International Conference on Business and Economic Research, Bandung, Indonesia, paper 1073.

https://www.academia.edu/9229684/A_STUDY_ON_HALAL_FOOD_AWARENESS_AMONG_MUSLIM_C USTOMERS_IN_KLANG_VALLEY?auto=download 
Aziz, AY, \& Vui, CN. (2013). The role of Halal awareness and Halal non-Muslim influencing certification in purchasing intention. Paper presented at the 3rd International Conference on Business and Economic Research (3rd ICBER 2012) Proceeding, 1819-1830. http://psasir.upm.edu.my/id/eprint/31869/

Khalek, AA, (2014). "Young consumers" JAKIM's halal certification in Malaysia "attitude towards halal food outlets and JAKIM's. Procedia - Social and Behavioral Sciences, 121(2014), 26 - 34 https://doi.org/10.1016/j.sbspro.2014.01.1105

Lada, S., Tanakinjal, HG, \& Amin, H. (2009). Predicting intention to choose halal products using the theory of reasoned action. International Journal of Islamic and Middle Eastern Finance and Management, 2(1), 66-76. https://doi.org/10.1108/17538390910946276

Norafni, FR, Zurina, S., Syahidawati, S. (2013). Awareness and Perception of Muslim Consumers on Non-Food Halal Products. Journal of Social and Development Sciences, 4(10), 478-487, Oct 2013 ISSN 2221- 1152. https://www.researchgate.net/publication/326582200_Halal_Awareness_on_the_Socialization_of_Halal_Certifi cation. DOI: 10.1088 / 1755-1315 / 175/1/012217

Rajagopal, S., Ramanan, S., Visvanathan, R., \& Satapathy, S. (2011). Halal certification: implication for marketers in UAE. Journal of Islamic Marketing, 2(2), 132-153. https://doi.org/10.1108/17590831111139857

Rohimah Mohamed Yunoes, Che Faridah Che Mahmood, Nur Hafizah Abd Mansor. (2014). Understanding Mechanism to promote halal industry the stakeholders' view. Procedia Social and behavioral science, 130, 160-166. https://doi.org/10.1016/j.sbspro.2014.04.020

Teng, PK, et al. (2013). Awareness, recognition, and intention: Insights from a non-Muslim consumer survey regarding Halal labeled food products in Malaysia. International Conference On Management. https://doi.org/10.13140/2.1.2822.8168

Teguh Widodo. (2013). The Influence of Muslim consumer's Perception Towards Halal food production attitude and purchase intention at retail stores. Business Economics Journal, 1, April 2013. https://www.neliti.com/publications/3973/the-influence-of-muslim- on

Yunus, SNNM, Wan, EWR, Norafifa, MA, Norhidayah, MR. (2014). Muslim's Purchase Intention towards Non-Muslim's Halal Packaged Food Manufacturer. Procedia - Social and Behavioral Sciences, 130(2014), 145 154. https://www.sciencedirect.com/science/article/pii/S1877042814029280

Yuli Mutiah, Syaad Afifuddin. (2012). Effect of inclusion of halal labels on instant noodle packaging on interest Muslim community defense. Journal of Economics and Finance, 1(1), University of North Sumatra. https://www.neliti.com/publications/14866 